\title{
An experimental study on the influences of wind erosion on water erosion
}

\author{
YANG Huimin ${ }^{1,2,3,4}$, GAO Yuan ${ }^{2,3}$, LIN Degen ${ }^{2,3}$, ZOU Xueyong ${ }^{1,5,6}$, WANG Jing'ai ${ }^{1,2,3}$, \\ SHI Peijun ${ }^{1,5,6^{*}}$

\footnotetext{
${ }^{1}$ State Key Laboratory of Earth Surface Processes and Resource Ecology, Beijing Normal University, Beijing 100875, China;

${ }^{2}$ Key Laboratory of Regional Geography, Beijing Normal University, Beijing 100875, China;

${ }^{3}$ School of Geography, Beijing Normal University, Beijing 100875, China;

${ }^{4}$ College of Life Science \& Technology, Hebei Normal University of Science \& Technology, Qinhuangdao 066000, China; 100875, China;

${ }^{6}$ Academy of Disaster Reduction and Emergency Management, Beijing Normal University, Beijing 100875, China
} \\ ${ }^{5}$ Key Laboratory of Environmental Change and Natural Disaster of Ministry of Education, Beijing Normal University, Beijing
}

\begin{abstract}
In semi-arid regions, complex erosion resulted from a combination of wind and water actions has led to a massive soil loss and a comprehensive understanding of its mechanism is the first step toward prevention of the erosion. However, the mutual influences between wind erosion and water erosion have not been fully understood. This research used a wind tunnel and two rainfall simulators and simulated two rounds of alternations between wind erosion and water erosion (i.e., $1^{\text {st }}$ wind erosion- $1^{\text {st }}$ water erosion and $2^{\text {nd }}$ wind erosion- $2^{\text {nd }}$ water erosion) on three slopes $\left(5^{\circ}, 10^{\circ}\right.$, and $\left.15^{\circ}\right)$ with six wind speeds $(0,9,11$, $13,15$, and $20 \mathrm{~m} / \mathrm{s})$ and five rainfall intensities $(0,30,45,60$, and $75 \mathrm{~mm} / \mathrm{h})$. The objective was to analyze the influences of wind erosion on succeeding water erosion. Results showed that the effects of wind erosion on water erosion were not the same in the two rounds of tests. In the $1^{\text {st }}$ round of tests, wind erosion first restrained and then intensified water erosion mostly because the blocking effect of wind-sculpted micro-topography on surface flow was weakened with the increase in slope. In the $2^{\text {nd }}$ round of tests, wind erosion intensified water erosion on beds with no rills at gentle slopes and low rainfall intensities or with large-size rills at steep slopes and high rainfall intensities. Wind erosion restrained water erosion on beds with small rills at moderate slopes and moderate rainfall intensities. The effects were mainly related to the fine grain layer, rills and slope of the original bed in the $2^{\text {nd }}$ round of tests. The findings can deepen our understanding of complex erosion resulted from a combination of wind and water actions and provide scientific references to regional soil and water conservation.
\end{abstract}

Keywords: wind-water interaction; sandy soil; particle size; surface roughness; wind and water erosion

Citation: YANG Huimin, GAO Yuan, LIN Degen, ZOU Xueyong, WANG Jing'ai, SHI Peijun. 2017. An experimental study on the influences of wind erosion on water erosion. Journal of Arid Land, 9(4): 580-590. doi: 10.1007/s40333-017-0004-8

\section{Introduction}

Complex erosion resulted from a combination of wind and water action usually refers to alternations between wind erosion in dry seasons and water erosion in wet seasons. Due to its fragile ecological environment and erratic weather conditions, complex erosion frequently occurs in the agricultural-pastoral ecotone of northern China (Shi and Wang, 1986; Wang et al., 2008; Ta et al., 2015). As compared with sole occurrence of wind erosion or sole occurrence of water

*Corresponding author: SHI Peijun (E-mail: spj@bnu.edu.cn)

Received 2016-04-28; revised 2017-04-07; accepted 2017-05-07

(C) Xinjiang Institute of Ecology and Geography, Chinese Academy of Sciences, Science Press and Springer-Verlag Berlin Heidelberg 2017 
erosion, complex erosion resulted from a combination of wind and water actions involves different erosion process and greater harm in these semi-arid agricultural-pastoral ecotones of northern China (Zou et al., 2003; Ren et al., 2011; Ta et al., 2015). Therefore, research on complex erosion is of great importance to accurately evaluate the soil erosion status and to improve the regional soil and water conservation.

Wind erosion and water erosion were usually studied separately. Previous studies focused on the influencing factors of these two kinds of erosions and these factors included roughness, particle size distribution, and structure of topsoil. For example, it was reported that wind erosion can destroy topsoil structure (Ekhtesasi and Sepehr, 2009), change topsoil particle size distribution (Lü and Dong, 2006; Dong and Qian, 2007) and reshape the micro-topography of bed surface, resulting in random roughness or oriented roughness of topsoil (Römkens and Wang, 1986; Zhao et al., 2006). For water erosion, increased surface random roughness formed by depressions and barriers was reported to impede runoff and thus decrease sediment yield (Johnson et al., 1979). Similarly, oriented roughness (e.g., rills) perpendicular to or intersecting with runoff direction at a high angle can reduce runoff and restrain water erosion (Song et al., 2006). In contrast, oriented roughness from upslope to downslope can concentrate water flow into drainage pathways (e.g., rills), resulting in higher scouring potential, and intensifying water erosion (Helming et al., 1998; Dunkerley and Brown, 1999).

Recently, the complex erosion resulted from a combination of wind and water actions has attracted scientific attentions (Field et al., 2009; Belnap et al., 2011; Wang et al., 2014; Ta et al., 2015) and some experiments have been conducted to analyze the relationship and interaction between wind erosion and water erosion (Song et al., 2007; Tuo et al., 2016; Zhang et al., 2016). For example, Tuo et al. (2016) simulated the wind erosion-water erosion effect on $15^{\circ}$ sandy loam bed. They found that wind erosion at the wind speeds of 11 and $14 \mathrm{~m} / \mathrm{s}$ increased the succeeding water erosion rates by $7.25 \%$ and $38.97 \%$, respectively, and that the influence of wind erosion on water erosion was weakened with the increased rainfall intensity. Zhang et al. (2016) studied the influence of complex erosion on sandy loess bed with artificial rills and found that wind erosion intensified the succeeding water erosion by changing the surface micro-topography. However, unlike the one-round (wind erosion and succeeding water erosion) and single gradient $\left(15^{\circ}\right.$ slope) experimental design in the above mentioned studies, the actual field situation can be much more complicated and the complicated situations need further investigation. This research used a wind tunnel and two rainfall simulators and simulated two rounds of alternations between wind erosion and water erosion (i.e., $1^{\text {st }}$ wind erosion- $1^{\text {st }}$ water erosion and $2^{\text {nd }}$ wind erosion- $2^{\text {nd }}$ water erosion) on three slopes $\left(5^{\circ}, 10^{\circ}\right.$, and $\left.15^{\circ}\right)$ with six wind speeds $(0,9,11,13,15$, and $20 \mathrm{~m} / \mathrm{s})$ and five rainfall intensities $(0,30,45,60$, and $75 \mathrm{~mm} / \mathrm{h})$. The objective was to analyze the influences of wind erosion on succeeding water erosion.

\section{Materials and methods}

\subsection{Soil collection and experimental equipment}

The experiment of complex erosion was carried out at the Fangshan Comprehensive Experimental Research Station of the State Key Laboratory of Earth Surface Processes and Resource Ecology, Beijing Normal University, China. The soil used in the experiment was a typical semi-fixed aeolian sandy soil $(0-20 \mathrm{~cm})$ and was collected from Zhenglan Banner $\left(42^{\circ} 12^{\prime} 51^{\prime \prime} \mathrm{N}\right.$, $116^{\circ} 01^{\prime} 42^{\prime \prime} \mathrm{E}$ ), Inner Mongolia, in the eastern section of the agricultural-pastoral ecotone in northern China, a typical area that experiences complex erosion resulted from a combination of wind and water actions (Wang et al., 2008). The proportions of clay $(0.01-2 \mu \mathrm{m})$, silt $(2-20 \mu \mathrm{m})$, fine sand $(20-200 \mu \mathrm{m})$, and coarse sand $(\geq 200 \mu \mathrm{m})$ in the soil samples were $0.08 \%, 2.46 \%$, $15.41 \%$, and $82.05 \%$, respectively.

The experimental instruments mainly included a wind tunnel and two rainfall simulators. Wind erosion was simulated in a blow-type wind tunnel made up of seven sections, namely, an air 
intake section, a fan section, a first diffusion section, a steady flow section, a contraction section, a working section and a second diffusion section (Fig. 1a). The glass-walled working section of the wind tunnel was $15.9 \mathrm{~m}$ long, $1.0 \mathrm{~m}$ wide and $1.0 \mathrm{~m}$ high. Wind speed in the working section varied from 2 to $35 \mathrm{~m} / \mathrm{s}$ with the fluctuation less than $1 \%$ and with the turbulence less than $0.8 \%$. Water erosion was simulated using two rainfall simulators (Fig. 1b), which were $3.5 \mathrm{~m}$ high such that the raindrop size and terminal speed were close to those of natural rainfall. The intensity of the simulated rainfall varied from 11.3 to $132.5 \mathrm{~mm} / \mathrm{h}$ and its heterogeneity exceeded $89 \%$ (Zhang et al., 2007; Xie et al., 2008).

Soil samples were collected in aluminum alloy soil boxes and the boxes were $1.5 \mathrm{~m}$ long, 0.45 $\mathrm{m}$ wide and $0.1 \mathrm{~m}$ high. Four stainless steel baffles $(0.07-\mathrm{m}$ high) were installed around each soil box to prevent runoff overflow. Small holes (approximately 1-mm in diameter) were evenly distributed on the bottom of soil boxes to produce natural-like infiltration and drainage.

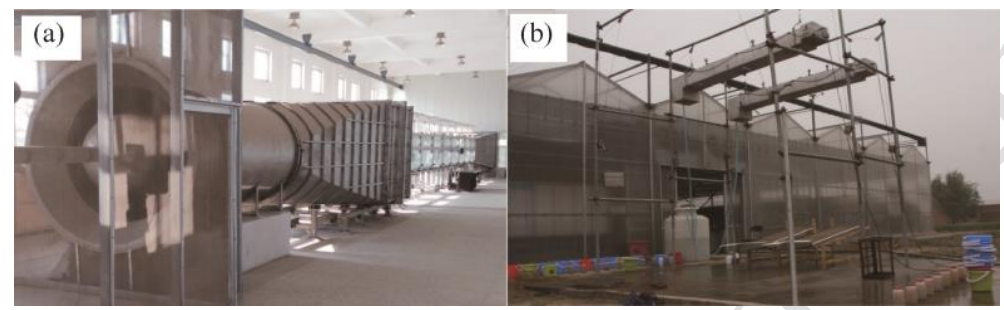

Fig. 1 Photos of the wind tunnel (a) and rainfall simulators (b)

\subsection{Experimental design}

In the experiment, each bed surface was subjected to two rounds of alternating wind and water erosion tests. The first round was labeled as " $1{ }^{\text {st }}$ wind erosion $-1^{\text {st }}$ water erosion" and the second round " $2^{\text {nd }}$ wind erosion- $2^{\text {nd }}$ water erosion". The experimental process corresponds to the field alternating wind and water erosion. Specifically, the $1^{\text {st }}$ wind erosion, $1^{\text {st }}$ water erosion, $2^{\text {nd }}$ wind erosion, $2^{\text {nd }}$ water erosion correspond to spring wind erosion, summer water erosion, winter and succeeding spring wind erosion, and succeeding summer water erosion, respectively. The experimental conditions including slope, wind speed and rainfall intensity are shown in Table 1.

Table 1 Experimental design of complex erosion by wind and water

\begin{tabular}{|c|c|c|c|c|c|}
\hline \multicolumn{4}{|c|}{$1^{\text {st }}$ and $2^{\text {nd }}$ wind erosions } & \multicolumn{2}{|c|}{$1^{\text {st }}$ and $2^{\text {nd }}$ water erosions } \\
\hline $\begin{array}{l}\text { Slope } \\
\left({ }^{\circ}\right)\end{array}$ & $\begin{array}{l}\text { Wind speed } \\
(\mathrm{m} / \mathrm{s})\end{array}$ & $\begin{array}{l}1^{\text {st }} \text { wind erosion } \\
\text { duration }(\mathrm{min})\end{array}$ & $\begin{array}{c}2^{\text {nd }} \text { wind erosion } \\
\text { duration (min) }\end{array}$ & $\begin{array}{l}\text { Slope } \\
\left({ }^{\circ}\right)\end{array}$ & $\begin{array}{l}\text { Rainfall intensity } \\
(\mathrm{mm} / \mathrm{h})\end{array}$ \\
\hline \multirow{6}{*}{0} & 0 & 0 & 0 & 5 & 0 \\
\hline & . & 1 & 1 & 10 & 30 \\
\hline & 11 & 2 & 2 & 15 & 45 \\
\hline & 13 & 3 & 6 & & 60 \\
\hline & 15 & 5 & 10 & & 75 \\
\hline & 20 & 10 & 10 & & \\
\hline
\end{tabular}

\subsection{Experimental process}

Prior to a test, the soil sample was sieved through a 5-mm sieve and then air-dried to a moisture content of approximately $0.25 \%$. Thereafter, an experimental soil box with the bottom lined with filter paper was filled with the processed soil to a depth of $10 \mathrm{~cm}$ and the soil bulk density was $1.30 \mathrm{~g} / \mathrm{cm}^{3}$. The soil surface was scraped to be smooth and flat.

The experimental steps: (1) once the soil box (i.e., soil bed) was prepared, it was moved into the wind tunnel for the $1^{\text {st }}$ wind erosion test with different wind speeds and durations (see Table 1); (2) after the $1^{\text {st }}$ wind erosion test, the soil bed was taken out immediately to the rain hall for the $1^{\text {st }}$ water erosion test with different rainfall intensities and slopes (also see Table 1). After 
runoff started, runoff water was collected continuously at 4-min intervals for $48 \mathrm{~min}$; (3) after the $1^{\text {st }}$ water erosion test, the soil bed was dried naturally to less than $0.25 \%$ moisture content and returned to the wind tunnel for the $2^{\text {nd }}$ wind erosion test; (4) following the $2^{\text {nd }}$ wind erosion test, the soil bed was taken out immediately to the rain hall for the $2^{\text {nd }}$ water erosion test and the runoff water was collected continuously at 4-min intervals for $48 \mathrm{~min}$.

In the wind erosion tests, a pitot tube was installed $0.3 \mathrm{~m}$ upwind from the soil bed and $0.1 \mathrm{~m}$ above the floor of the working section of the wind tunnel to measure the wind speed. The wind speed was calibrated to be within $\pm 0.2 \%$ of the designed wind speed. Soil boxes were placed on the most stable position at $10 \mathrm{~m}$ downwind of the working section. In view of the limited height $(1.0 \mathrm{~m})$ of the working section, soil boxes were positioned without slope differences in the same horizontal plane as the floor of the working section.

In the water erosion tests, rainfall intensities were calibrated to be within $\pm 2 \%$ of the designed ones. Soil boxes were placed on a wooden frame that could be adjusted freely to achieve slopes of $5^{\circ}, 10^{\circ}$, and $15^{\circ}$, and the runoff direction was the same as the wind direction of the previous wind erosion test.

\subsection{Measurements}

Wind erosion amount was determined as the weight difference of each soil box before and after the wind erosion, while water erosion amount was determined by weighing sediments in the runoff water collected. Soil boxes were weighed using a high-precision electronic scale (KCC150, Toledo Mettler Company, Germany), which has a $\pm 1 \mathrm{~g}$ accuracy. Sediments in runoff water collected were dried at $105^{\circ} \mathrm{C}$ for $24 \mathrm{~h}$ until constant mass and then weighed with an electronic scale (SE601F, OHAUS Corporation, China), which has a $\pm 0.1 \mathrm{~g}$ accuracy.

Soil particle size of mixed soil sample (within $0-0.5 \mathrm{~cm}$ of the topsoil at the front, middle and tail of the bed) was determined using a Malvern Particle Size Analyzer (MS2000, Malvern Instrument Company, UK) and the precision was better than $1 \%$ within the particle size range of $0.02-2000 \mu \mathrm{m}$. Distilled water was used as the dispersant.

Bed elevation before and after each wind (water) erosion test was measured using a three-dimensional laser scanner (3-D laser scanner, GX-DR200+3D, Trimble Navigation Limited, USA). The accuracy of the scanner was $1.4 \mathrm{~mm}$ within the scanning distance of $50 \mathrm{~m}$. The scanning distance used in this study was within $7 \mathrm{~m}$.

\subsection{Calculations}

\subsubsection{Soil erosion rate}

Soil erosion rate $\left(Q, \mathrm{~g} /\left(\mathrm{m}^{2} \cdot \mathrm{min}\right)\right)$ is the soil erosion amount per unit time per unit area. It is calculated using the following equation.

$$
Q=M /(T \times S),
$$

where, $M$ is the soil erosion amount $(\mathrm{g}) ; T$, the soil erosion duration (min); and $S$, the area of the soil bed $\left(\mathrm{m}^{2}\right)$.

\subsubsection{Surface roughness}

Surface roughness reflects the micro-topographic fluctuations of the soil surface. As one of the most common and simple parameters, the standard deviation of point elevations is often used to quantify surface roughness (Allmaras et al., 1966).

$$
R R=\left\{\frac{1}{n-1} \sum_{i=1}^{n}\left[H(i)-{ }_{i}\right]^{2}\right\}^{\frac{1}{2}},
$$

where, $R R$ is the surface roughness $(\mathrm{mm}) ; n$, the number of observed points; $H\left(x_{i}\right)$, the elevation of point $\left(x_{i}\right) ; \bar{H}$, the average elevation of all points $\left\{x_{i}\right\}$.

Generally, the greater $R R$ is, the rougher the surface will be. $R R$, however, can only characterize random roughness and is unable to reflect oriented roughness. Oriented roughness characterization requires other parameters, such as the size and direction of sand ripples and rills. 


\section{Results}

\subsection{Effects of wind erosion on water erosion in the $1^{\text {st }}$ round of tests}

\subsubsection{Topsoil particle size}

Topsoil particle size is an important influencing factor of soil erodibility and can also be significantly affected by wind erosion. As shown in Table 2, after the $1^{\text {st }}$ wind erosion tests, topsoil particle size increased under all the wind speeds and exhibited spatial differences. The particle size of sand ripples formed at the tail of the bed surface was observed to be bigger than that of blowout pits at the forepart (Fig. 2a). The particle size of sand ripple peaks was bigger than that of troughs (Fig. 2b).

Table 2 Changes of topsoil particle size in the $1^{\text {st }}$ round of wind erosion tests

\begin{tabular}{crrrrr}
\hline \multirow{2}{*}{ Particle size } & \multicolumn{5}{c}{ Wind speed $(\mathrm{m} / \mathrm{s})$} \\
\cline { 2 - 6 } & 9 & 11 & 13 & 15 & 20 \\
\hline$\Phi_{o 1}(\mu \mathrm{m})$ & 385.6 & 385.6 & 385.6 & 385.6 & 385.6 \\
$\Phi_{w 1}(\mu \mathrm{m})$ & 447.1 & 481.1 & 490.4 & 474.6 & 468.4 \\
$\Delta \Phi_{1}(\%)$ & 15.9 & 24.8 & 27.2 & 23.1 & 21.5 \\
\hline
\end{tabular}

Note: $\Phi_{o 1}$, particle size of the original surface; $\Phi_{w 1}$, average particle size of bed surfaces experiencing wind erosion; $\Delta \Phi_{1}$, particle size change; $\Delta \Phi_{1}=\left(\Phi_{w 1}-\Phi_{o 1}\right) / \Phi_{o 1} \times 100 \%$.

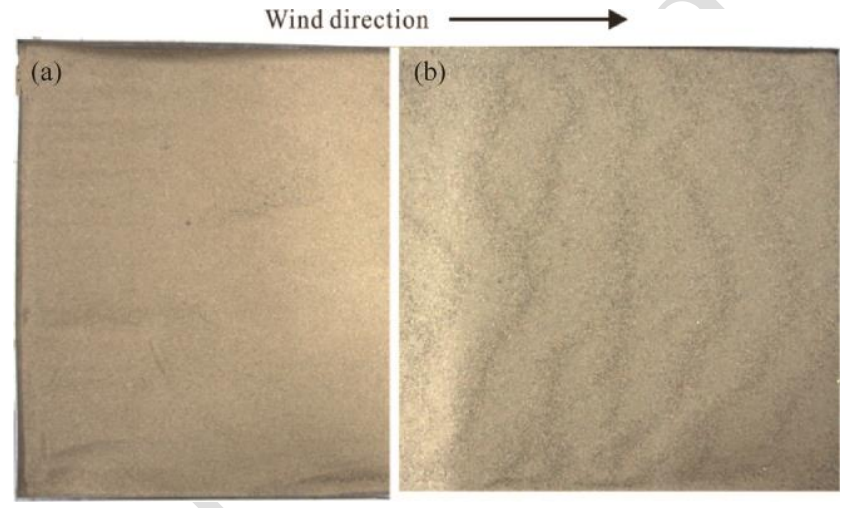

Fig. 2 Blowout pits formed at the forepart of the bed surface and sand ripples (a) and formed at the tail (b, sand ripple peaks appear dark and troughs appear light)

\subsubsection{Surface roughness}

Wind erosion increased bed surface roughness by reshaping the micro-topography, consequently producing blowout pits, and sand ripples. After the $1^{\text {st }}$ wind erosion test, blowout pits were about $45 \mathrm{~cm}$ wide, $30-60 \mathrm{~cm}$ long, $0.5-3.0 \mathrm{~cm}$ deep; sand ripples were about 5-15 cm in wavelength and $0.5-5.0 \mathrm{~mm}$ in wave height (Fig. 3a); bed surface roughness increased under all the wind speeds (Table 3 ).

\subsubsection{Water erosion rate}

Table 4 shows the average water erosion rate $\left(Q_{w 1}\right)$ of bed surfaces after wind erosion at various wind speeds and the water erosion rate $\left(Q_{o 1}\right)$ of the control. It can be seen that with the increase in rainfall intensity, the water erosion rate of bed surfaces with the same slope increased, and the increment became larger with the increase in the slope.

The influence of the $1^{\text {st }}$ wind erosion on the $1^{\text {st }}$ water erosion is complex. Among the 12 groups of tests ( 3 slopes $\times 4$ rainfall intensities), 8 groups showed intensifying effect (i.e., the positive values of $\Delta Q_{2}$ in Table 4), while 4 restraining effect (i.e., the negative values of $\Delta Q_{2}$ in Table 4). Therefore, wind erosion mainly intensified water erosion in the $1^{\text {st }}$ round of tests. The number of groups with positive water erosion rate change $\left(\Delta Q_{1}\right)$ is $1,3,4$ on the $5^{\circ}, 10^{\circ}$, and $15^{\circ}$ slopes, respectively, indicating that wind erosion first restrained and then intensified water erosion with increasing slope. On bed surfaces with the same slope, the influence of wind erosion on water 
erosion is not all the same, maybe due to the micro-topography differences caused by wind erosion. For example, on $5^{\circ}$ slope, wind erosion intensified water erosion at the rainfall intensity of $45 \mathrm{~mm} / \mathrm{h}$, while restrained under other rainfall intensities.
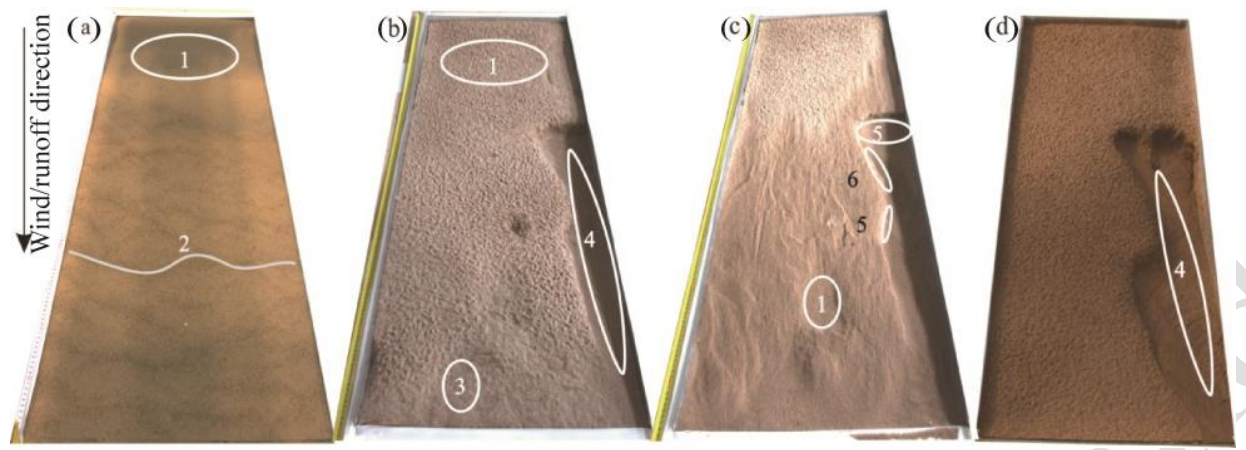

Fig. 3 Photos of a bed surface after (a) $1^{\text {st }}$ wind erosion $(15 \mathrm{~m} / \mathrm{s})$, (b) $1^{\text {st }}$ water erosion $(75 \mathrm{~mm} / \mathrm{h})$, (c) $2^{\text {nd }}$ wind erosion $(15 \mathrm{~m} / \mathrm{s})$, and (d) $2^{\text {nd }}$ water erosion $(75 \mathrm{~mm} / \mathrm{h})$. In the photos above, 1 designates a blowout pit; 2 , sand ripples; 3 , embryonic form of a rill; 4 , a rill; 5 , a deposition location; and 6 , a lateral erosion location.

Table 3 Changes of surface roughness in the $1^{\text {st }}$ round of wind erosion tests

\begin{tabular}{|c|c|c|c|c|c|}
\hline \multirow{2}{*}{ Surface roughness } & \multicolumn{5}{|c|}{ Wind speed $(\mathrm{m} / \mathrm{s})$} \\
\hline & 9 & 11 & 13 & 15 & 20 \\
\hline$R_{o 1}(\mathrm{~mm})$ & 2.8 & 1.9 & 2.0 & 2.2 & 2.4 \\
\hline$R_{w 1}(\mathrm{~mm})$ & 3.0 & 2.2 & 3.0 & 3.6 & 5.6 \\
\hline$\Delta R_{1}(\%)$ & 7.1 & 15.8 & 50.0 & 63.6 & 133.3 \\
\hline
\end{tabular}

Note: $R_{o 1}$, roughness of the original surface; $R_{w 1}$, average roughness of bed surfaces experiencing wind erosion; $\Delta R_{1}$, surface roughness change; $\Delta R_{1}=\left(R_{w 1}-R_{o 1}\right) / R_{o 1} \times 100 \%$.

Table 4 Effect of wind erosion on water erosion under different slopes and rainfall intensities in the $1^{\text {st }}$ round of tests

\begin{tabular}{|c|c|c|c|c|c|}
\hline \multirow{2}{*}{ Slope $\left({ }^{\circ}\right)$} & \multirow{2}{*}{ Water erosion rate } & & \multicolumn{2}{|c|}{ Rainfall intensity $(\mathrm{mm} / \mathrm{h})$} & \multirow[b]{2}{*}{75} \\
\hline & & 30 & 45 & 60 & \\
\hline \multirow{3}{*}{5} & $Q_{o 1}\left(\mathrm{~g} /\left(\mathrm{m}^{2} \cdot \min \right)\right)$ & 0.16 & 0.29 & 3.27 & 7.64 \\
\hline & $Q_{w 1}\left(\mathrm{~g} /\left(\mathrm{m}^{2} \cdot \mathrm{min}\right)\right)$ & 0.09 & 0.63 & 1.43 & 6.56 \\
\hline & $\Delta Q_{1}(\%)$ & -43.75 & 117.24 & -56.27 & -14.14 \\
\hline \multirow{3}{*}{10} & $Q_{o 1}\left(\mathrm{~g} /\left(\mathrm{m}^{2} \cdot \mathrm{min}\right)\right)$ & 0.12 & 3.53 & 8.68 & 20.99 \\
\hline & $Q_{w 1}\left(\mathrm{~g} /\left(\mathrm{m}^{2} \cdot \min \right)\right)$ & 0.44 & 1.34 & 17.30 & 24.49 \\
\hline & $\Delta Q_{1}(\%)$ & 266.67 & -62.04 & 99.31 & 16.67 \\
\hline \multirow{3}{*}{15} & $Q_{o 1}\left(\mathrm{~g} /\left(\mathrm{m}^{2} \cdot \mathrm{min}\right)\right)$ & 0.10 & 5.62 & 12.18 & 33.41 \\
\hline & $Q_{w 1}\left(\mathrm{~g} /\left(\mathrm{m}^{2} \cdot \min \right)\right)$ & 2.45 & 6.98 & 21.91 & 79.00 \\
\hline & $\Delta Q_{1}(\%)$ & 2350.00 & 24.19 & 79.89 & 136.46 \\
\hline
\end{tabular}

Note: $Q_{o 1}$, water erosion rate of bed surface with no wind erosion (control) in the $1^{\text {st }}$ round of tests; $Q_{w 1}$, average water erosion rate of bed surfaces after wind erosion in the $1^{\text {st }}$ round of tests; $\Delta Q_{1}$, water erosion rate change caused by wind erosion in the $1^{\text {st }}$ round of tests; $\Delta Q_{1}=\left(Q_{w 1}-Q_{o 1}\right) / Q_{o 1} \times 100 \%$.

\subsection{Effects of wind erosion on water erosion in the $2^{\text {nd }}$ round of tests}

\subsubsection{Original bed of the $2^{\text {nd }}$ round of tests}

The original soil bed of the $1^{\text {st }}$ round of tests was uniform, while that of the $2^{\text {nd }}$ round of tests was different. Prior to the $2^{\text {nd }}$ wind erosion tests, soil beds that were subjected to the $1^{\text {st }}$ water erosion tests and to natural drying presented three obvious layers from the surface to the bottom, namely, a coarsening layer with very thin crust, a fine grain layer with certain hardness, and a sand layer (Fig. 4). Average particle sizes of the three layers were 453.9, 363.3, and $388.6 \mu \mathrm{m}$, respectively. 


\subsubsection{Topsoil particle size}

As shown in Table 5, after the $2^{\text {nd }}$ round of wind erosion tests, topsoil particle size (sum of products of respective exposed area ratio and mean particle size of the three layers described above) decreased under all the wind speeds. The reason is that with the increase of wind speed, the wind erosion range extended from coarsening layer at the tail of the bed to the forepart, therefore decreasing the exposed area of the coarsening layer and thus increasing the exposed areas of the fine grain layer and the sand layer. As a result, the topsoil particle size gradually decreased.

\subsubsection{Surface roughness}

As shown in Table 6 , after the $2^{\text {nd }}$ round of wind erosion tests, surface roughness decreased under various wind speeds. With the increase in wind speed, the decrease of surface roughness first became larger and then smaller. Specifically, surface roughness quickly decreased under the wind speeds of $11-15 \mathrm{~m} / \mathrm{s}$ due to wind abrasion of inter-rills, and then slowly decreased with wind speed further increased from 15 to $20 \mathrm{~m} / \mathrm{s}$ when wind abrasion of the rill walls became obvious and surface roughness increased to some extent. For example, roughness change $\left(\Delta R_{2}\right)$ was smaller at the wind speed of $20 \mathrm{~m} / \mathrm{s}$ than at the wind speed of $15 \mathrm{~m} / \mathrm{s}$ (Fig. 3c).

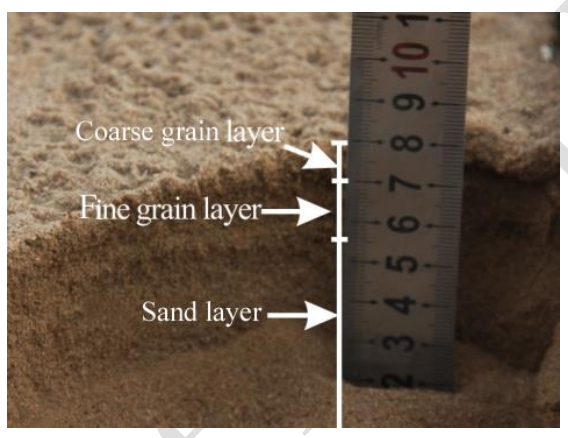

Fig. 4 Soil stratification after the $1^{\text {st }}$ round of water erosion tests

Table 5 Changes of topsoil particle size in the $2^{\text {nd }}$ round of wind erosion tests

\begin{tabular}{cccccc}
\hline \multirow{2}{*}{ Particle size } & \multicolumn{5}{c}{ Wind speed $(\mathrm{m} / \mathrm{s})$} \\
\cline { 2 - 6 } & 9 & 11 & 13 & 15 & 20 \\
\hline$\Phi_{o 2}(\mu \mathrm{m})$ & 453.9 & 453.9 & 453.9 & 453.9 & 453.9 \\
$\Phi_{w 2}(\mu \mathrm{m})$ & 453.9 & 453.9 & 452.5 & 438.2 & 434.0 \\
$\Delta \Phi_{2}(\%)$ & 0.00 & 0.00 & -0.30 & -3.50 & -4.40 \\
\hline
\end{tabular}

Note: $\Phi_{o 2}$, particle size of the original surface; $\Phi_{w 2}$, average particle size of bed surfaces experiencing wind erosion; $\Delta \Phi_{2}$, particle size change; $\Delta \Phi_{2}=\left(\Phi_{w 2}-\Phi_{o 2}\right) / \Phi_{o 2} \times 100 \%$.

Table 6 Changes of surface roughness in the $2^{\text {nd }}$ round of wind erosion tests

\begin{tabular}{cccccc}
\hline \multirow{2}{*}{ Surface roughness } & \multicolumn{5}{c}{ Wind speed $(\mathrm{m} / \mathrm{s})$} \\
\cline { 2 - 6 } & 9 & 11 & 13 & 15 & 20 \\
\hline$R_{o 2}(\mathrm{~mm})$ & 3.5 & 2.7 & 3.1 & 3.9 & 5.3 \\
$R_{w 2}(\mathrm{~mm})$ & 3.5 & 2.6 & 2.9 & 3.3 & -15.4 \\
$\Delta R_{2}(\%)$ & 0.0 & -3.7 & -6.5 & -11.3 \\
\hline
\end{tabular}

Note: $R_{o 2}$, roughness of the original surface; $R_{w 2}$, average roughness of bed surfaces experiencing wind erosion; $\Delta R_{2}$, surface roughness change; $\Delta R_{2}=\left(R_{w 2}-R_{o 2}\right) / R_{o 2} \times 100 \%$.

\subsubsection{Effects of wind erosion on water erosion rate}

Table 7 shows the average water erosion rate of bed surfaces $\left(Q_{w 2}\right)$ and water erosion rate of the control $\left(Q_{o 2}\right)$ after wind erosion at various wind speeds. It can be seen that with the increase in rainfall intensity, the water erosion rate of bed surfaces increased under the same slope conditions.

The effect of the $2^{\text {nd }}$ wind erosion on the $2^{\text {nd }}$ water erosion is complex. Among the 12 groups of 
tests ( 3 slopes $\times 4$ rainfall intensities), 8 groups showed restraining effect, while the remaining 4 groups existed intensifying effect. The restraining effect can be attributed to the structure of fine grain layer. In contrast, wind erosion intensified water erosion on $10^{\circ}$ slope under $60 \mathrm{~mm} / \mathrm{h}$ rainfall intensity and $15^{\circ}$ slope under $75 \mathrm{~mm} / \mathrm{h}$ rainfall intensity due to the generation of rills.

Table 7 Effect of wind erosion on water erosion under different slopes and rainfall intensities in the $2^{\text {nd }}$ round of tests

\begin{tabular}{|c|c|c|c|c|c|}
\hline \multirow{2}{*}{ Slope $\left(^{\circ}\right)$} & \multirow{2}{*}{ Water erosion rate } & \multicolumn{4}{|c|}{ Rainfall intensity (mm/h) } \\
\hline & & 30 & 45 & 60 & 75 \\
\hline \multirow{3}{*}{5} & $Q_{o 2}\left(\mathrm{~g} /\left(\mathrm{m}^{2} \cdot \mathrm{min}\right)\right)$ & 0.08 & 0.50 & 2.22 & 6.69 \\
\hline & $Q_{w 2}\left(\mathrm{~g} /\left(\mathrm{m}^{2} \cdot \mathrm{min}\right)\right)$ & 0.10 & 0.83 & 0.56 & 2.99 \\
\hline & $\Delta Q_{2}(\%)$ & 25.00 & 66.00 & -74.77 & -55.31 \\
\hline \multirow{3}{*}{10} & $Q_{o 2}\left(\mathrm{~g} /\left(\mathrm{m}^{2} \cdot \mathrm{min}\right)\right)$ & 1.59 & 5.12 & 9.11 & 28.17 \\
\hline & $Q_{w 2}\left(\mathrm{~g} /\left(\mathrm{m}^{2} \cdot \min \right)\right)$ & 0.18 & 0.38 & 10.57 & 11.75 \\
\hline & $\Delta Q_{2}(\%)$ & -88.68 & -92.58 & 16.03 & -58.29 \\
\hline \multirow{3}{*}{15} & $Q_{o 2}\left(\mathrm{~g} /\left(\mathrm{m}^{2} \cdot \min \right)\right)$ & 0.44 & 5.19 & 34.14 & 71.82 \\
\hline & $Q_{w 2}\left(\mathrm{~g} /\left(\mathrm{m}^{2} \cdot \min \right)\right)$ & 0.37 & 0.69 & 24.10 & 108.12 \\
\hline & $\Delta Q_{2}(\%)$ & -15.91 & -86.71 & -29.41 & 50.54 \\
\hline
\end{tabular}

Note: $Q_{o 2}$, water erosion rate of bed surface with no wind erosion in the $2^{\text {nd }}$ round of tests; $Q_{w 2}$, average water erosion rate of bed surfaces after wind erosion in the $2^{\text {nd }}$ round of tests; $\Delta Q_{2}$, changes of water erosion rate caused by wind erosion in the $2^{\text {nd }}$ round of tests; $\Delta Q_{2}=\left(Q_{w 2}-Q_{o 2}\right) / Q_{o 2} \times 100 \%$.

\section{Discussion}

\subsection{Effect of topsoil particle size on water erosion}

Wind erosion may affect the succeeding water erosion rate by changing the topsoil particle size. For water erosion, the characteristics of individual rainfall events determine the detachability and transportability of particles (Erpul et al., 2008), while topsoil particle size affects the soil anti-erodibility and further influences the soil erosion amount (Sharma, 1996; Zhang et al., 2011). The topsoil particle size has been changed by the two rounds of tests (Ekhtesasi and Sepehr, 2009). In the $1^{\text {st }}$ round of tests, topsoil particle size increased under all wind speeds, therefore restrained runoff transportation and resulted in a reduced water erosion rate, being consistent with the findings of $\mathrm{Xu}(2005)$ and Tuo et al. (2016). However, in the $2^{\text {nd }}$ round of tests, topsoil particle size decreased with increasing wind speed, promoting the runoff transportation to some extent. Therefore, wind erosion exerts different influences on the succeeding water erosion under different scenarios or condition combinations (e.g., slopes and rainfall intensities).

\subsection{Effect of surface roughness on water erosion}

Wind erosion may affect the succeeding water erosion rate by changing surface roughness. Aeolian and fluvial processes-induced changes in topography were widespread in the regions of complex erosion resulted from a combination of wind and water actions (Liu and Coulthar, 2015). The results from the two rounds of tests also showed that both wind erosion and water erosion have distinct effects on micro-topography. The micro-topographies included sand ripples and blowout pits generated by wind erosion in the $1^{\text {st }}$ round of tests and also included lateral abrasion of rill walls and blowout pits formed by wind erosion in the $2^{\text {nd }}$ round of tests (Zhang et al., 2016). The common changes in micro-topography were observed in both rounds of tests and they included headward erosion and collapse of rill walls by water erosion. In brief, the changes in micro-topography by complex erosion resulted from a combination of wind and water actions were different from those by sole wind erosion or sole water erosion (Bullard and Livingstone, 2002; Song et al., 2006; Field et al., 2009).

Changes in bed surface micro-topography were characterized by the changes in the random and oriented roughness (Römkens and Wang, 1986; Saleh, 1993; Zhao et al., 2006). Increased random 
roughness can impede runoff and decrease sediment yield (Johnson et al., 1979), while increased oriented roughness from upslope to downslope can concentrate water flow into drainage pathways and can thus result in a higher sediment yield and more runoff (Helming et al., 1998; Dunkerley and Brown, 1999). In the $1^{\text {st }}$ round of tests, wind erosion increased surface roughness, therefore decreased sediment yield on the $5^{\circ}$ and $10^{\circ}$ slopes. With the slope increased, the blocking effect of random roughness was weakened, being consistent with the finding of Tuo et al. (2016). In the $2^{\text {nd }}$ round of tests, wind erosion decreased surface roughness, but the effect was partially offset by the lateral abrasion of sand-laden airflow at higher wind speeds. For example, at wind speed of 20 $\mathrm{m} / \mathrm{s}$, the lateral abrasion of sand-laden airflow intensified in the rills, resulting in the suspension and collapse of rill walls (Zhang et al., 2016). Therefore, wind erosion restrained the succeeding water erosion at smaller wind speeds, while wind erosion at wind speed of $20 \mathrm{~m} / \mathrm{s}$ intensified water erosion under rainfall intensity of $75 \mathrm{~mm} / \mathrm{h}$ on $15^{\circ}$ slope.

\subsection{Effect of wind erosion on succeeding water erosion}

Wind erosion affected the succeeding water erosion via different mechanisms. In the $1^{\text {st }}$ round of tests, the intensifying or restraining effect of wind erosion on water erosion was mainly related to surface micro-topography (including sand ripples and blowout pits) and slope (Bullard and Livingstone, 2002). On the $5^{\circ}$ and $10^{\circ}$ slopes, sand ripples and blowout pits can obviously impede surface flow, resulting in the restraining effect (Römkens et al., 2002; Gómez and Nearing, 2005). On the $15^{\circ}$ slope, however, sand ripples and blowout pits can easily be broken by surface flow, resulting in the intensifying effect. Our finding, i.e., wind erosion intensified the succeeding water erosion on the $15^{\circ}$ slope, is consistent with Tuo et al. (2016) and Zhang et al. (2016).

Rainfall intensity also influenced the effect of wind erosion on water erosion. Under higher rainfall intensity, runoff can easily break sand ripples and blowout pits (Darboux and Huang, 2005), thus weakening the micro-topographic restraining effect on water erosion. For example, on the $15^{\circ}$ slope, the intensifying effect of wind erosion on water erosion became obvious when rainfall intensity increased from 45 to $75 \mathrm{~mm} / \mathrm{h}$. In contrast, Tuo et al. (2016) found the intensifying effect was weakened when rainfall intensity increased from 60 to $100 \mathrm{~mm} / \mathrm{h}$, since the influence of wind erosion on water erosion decreased under higher rainfall intensities. Therefore, it can be inferred that wind erosion has obvious influence on water erosion within a certain range of rainfall intensity.

In the $2^{\text {nd }}$ round of tests, the intensifying or restraining effect of wind erosion on water erosion was mainly related to the fine grain layer, rills and slope of the original bed. Under gentle slope and low rainfall intensity scenario $(5 \% / 30 \mathrm{~mm} / \mathrm{h}$ and $5 \% / 45 \mathrm{~mm} / \mathrm{h}$, respectively) and steep slope and high rainfall intensity scenario $(10 \% 60 \mathrm{~mm} / \mathrm{h}$ and $15 \% / 75 \mathrm{~mm} / \mathrm{h}$, respectively), wind erosion intensified water erosion via different mechanisms. In the former case, wind blew away the coarsening layer and exposed the fine grain layer with poor water permeability, and thus surface flow formed easily. Furthermore, topsoil particle size decreased after wind erosion. As a result, more topsoil particles were eroded and transported, and water erosion was thus intensified. In the latter case, large-size rills developed in the $1^{\text {st }}$ water erosion tests and facilitated lateral erosion in rills in the $2^{\text {nd }}$ wind erosion tests. With stronger lateral erosion, rill walls protruded and suspended obviously and became easier to collapse in the $2^{\text {nd }}$ water erosion tests (Shen et al., 2015, 2016). Therefore, water erosion was intensified. Under other slopes and rainfall intensities, small-size rills developed in the $1^{\text {st }}$ water erosion tests and the rills cut through the fine grain layer. Together with the $2^{\text {nd }}$ wind abrasion, more surface flow was changed to subsurface flow. Therefore, sediments decreased and water erosion was restrained.

In addition, clay content in soil samples also affects the influence of wind erosion on water erosion. According to previous research, for soil samples with higher clay content, bed surfaces coarsen easily and oriented roughness develops after wind erosion. Therefore, wind erosion can intensify the succeeding water erosion on $15^{\circ}$ slope (Tuo et al., 2016). However, crusts that form on bed surface experiencing water erosion and natural drying can obviously restrain succeeding wind erosion (Song et al., 2007). Therefore, in the $2^{\text {nd }}$ and later round of alternating erosion by wind and water, wind erosion has little effect on the succeeding water erosion unless the crust is destroyed. That is, for a soil with high clay content, the effect of wind erosion on water erosion 
only exists in the first round of alternating wind and water erosion. In this study, it was found that, for a soil with relatively lower clay content, wind erosion intensified the succeeding water erosion on $15^{\circ}$ slope. After water erosion and natural drying, very thin crust and fine grain layer with certain hardness formed on bed surfaces (Rajot et al., 2003). As a result, topsoil could be still eroded by airflow in the $2^{\text {nd }}$ round of tests and later. So, wind erosion affects water erosion in the whole process of alternating erosion by wind and water.

Overall, in alternating erosion by wind and water, the sediment yield of water erosion was closely related to wind erosion, and also affected by rainfall intensity and soil type. Therefore, the effects of wind erosion on water erosion under different scenarios should be considered to effectively prevent and control water erosion in the complex erosion area.

\section{Conclusions}

The effects of wind erosion on water erosion were not the same in the two rounds of tests. In the $1^{\text {st }}$ round of tests, wind erosion mainly intensified water erosion through increasing topsoil particle size and surface roughness. With the slope increased, the blocking effect of surface roughness on surface flow was weakened; therefore wind erosion first restrained and then intensified water erosion. In the $2^{\text {nd }}$ round of tests, wind erosion mainly restrained water erosion. The effect of wind erosion on water erosion is mainly related to the fine grain layer and rills of the original bed. Specifically, wind erosion intensified water erosion on beds with no rills at gentle slopes and low rainfall intensities or large-size rills at steep slopes and high rainfall intensities, while wind erosion restrained water erosion on beds with small rills at moderate slopes and moderate rainfall intensities.

The findings of this research can deepen our understanding of complex erosion resulted from a combination of wind and water actions and provide scientific references to regional soil and water conservation. However, it is essential to further study the influence of water erosion on wind erosion with the focus on long-term alternating wind and water erosion processes to fully understand the interactions between wind erosion and water erosion.

\section{Acknowledgements}

This research was supported by the National Natural Science Foundation of China (41271286) and the Innovative Research Group Project of the National Natural Science Foundation of China (413221001).

\section{References}

Allmaras R R, Burwell R E, Larson W E, et al. 1966. Total porosity and random roughness of the interrow zone as influenced by tillage. Consewation Research Report No. 7. Washington: U.S. Department of Agriculture, 34-46.

Belnap J, Munson S M, Field J P. 2011. Aeolian and fluvial processes in dryland regions: the need for integrated studies. Ecohydrology, 4(5): 615-622.

Bullard J E, Livingstone I. 2002. Interactions between aeolian and fluvial systems in dryland environments. Area, 34(1): 8-16.

Darboux F, Huang C H. 2005. Does soil surface roughness increase or decrease water and particle transfers? Soil Science Society of America Journal, 69(3): 748-756.

Dong Z B, Qian G Q. 2007. Characterizing the height profile of the flux of wind-eroded sediment. Environmental Geology, 51(5): 835-845.

Dunkerley D L, Brown K J. 1999. Banded vegetation near BRroken Hill, Australia: significance of surface roughness and soil physical properties. CATENA, 37(1-2): 75-88.

Ekhtesasi M R, Sepehr A. 2009. Investigation of wind erosion process for estimation, prevention, and control of DSS in Yazd-Ardakan plain. Environmental Monitoring and Assessment, 159(1-4): 267-280.

Erpul G, Gabriëls D, Cornelis W M, et al. 2008. Sand detachment under rains with varying angle of incidence. CATENA, 72(3): 413-422.

Field J P, Breshears D D, Whicker J J. 2009. Toward a more holistic perspective of soil erosion: Why aeolian research needs to explicitly consider fluvial processes and interactions. Aeolian Research, 1(1-2): 9-17.

Gómez J A, Nearing M A. 2005. Runoff and sediment losses from rough and smooth soil surfaces in a laboratory experiment. 
CATENA, 59(3): 253-266.

Helming K, Römkens M J M, Prasad S N. 1998. Surface roughness related processes of runoff and soil loss: A flume study. Soil Science Society of America Journal, 62(1): 243-250.

Johnson C B, Mannering J V, Moldenhauer W C. 1979. Influence of surface roughness and clod size and stability on soil and water losses. Soil Science Society of America Journal, 43(4): 772-777.

Liu B L, Coulthard T J. 2015. Mapping the interactions between rivers and sand dunes: Implications for fluvial and aeolian geomorphology. Geomorphol, 231: 246-257.

Lü P, Dong Z B. 2006. Wind tunnel experiments on the turbulent transmission over the near surface layer of different surfaces. Environmental Geology, 50(7): 983-988.

Rajot J L, Alfaro S C, Gomes L, et al. 2003. Soil crusting on sandy soils and its influence on wind erosion. CATENA, 53(1): $1-16$.

Ren C Y, Wang Z M, Song K S, et al. 2011. Spatial variation of soil organic carbon and its relationship with environmental factors in the farming-pastoral ecotone of Northeast China. Fresenius Environmental Bulletin, 20(1A): 253-261.

Römkens M J M, Wang J Y. 1986. Effect of tillage on surface roughness. Transactions of the ASAE, 29(2): 429-433.

Römkens M J M, Helming K, Prasad S N. 2002. Soil erosion under different rainfall intensities, surface roughness, and soil water regimes. CATENA, 46(2-3): 103-123.

Saleh A. 1993. Soil roughness measurement: Chain method. Journal of Soil and Water Conservation, 48(6): 527-529.

Sharma P P. 1996. Interrill erosion. In: Agassi M. Soil Erosion, Conservation, and Rehabilitation. New York: Marcel Dekker, $125-152$.

Shen H O, Zheng F L, Wen L L, et al. 2015. An experimental study of rill erosion and morphology. Geomorphology, 231: 193-201.

Shen H O, Zheng F L, Wen L L, et al. 2016. Impacts of rainfall intensity and slope gradient on rill erosion processes at loessial hillslope. Soil and Tillage Research, 155: 429-436.

Shi P J, Wang J A. 1986. Study on the landform characteristics by aeolian-fluvial interaction and its development process. Journal of Inner Mongolia Forestry College, 8(2): 88-97. (in Chinese)

Song Y, Yan P, Liu L Y. 2006. A review of the research on complex erosion by wind and water. Journal of Geographical Sciences, 16(2): 231-241.

Song Y, Yan P, Liu L Y, et al. 2007. Simulated experiment of erosion by wind and rainfall on sandy loess in Weiliantan Gully. Journal of Desert Research, 27(5): 814-819. (in Chinese)

Ta W Q, Wang H B, Jia X P. 2015. The contribution of aeolian processes to fluvial sediment yield from a desert watershed in the Ordos Plateau, China. Hydrological Processes, 29(1): 80-89.

Tuo D F, Xu M X, Gao L Q, et al. 2016. Changed surface roughness by wind erosion accelerates water erosion. Journal of Soils and Sediments, 16(1): 105-114.

Wang T, Qu J J, Yao Z Y, et al. 2008. Current status and comprehensive control strategies of soil erosion for wind-water complex erosion region in the Northern agro-pasture zigzag zone of China. Science of Soil and Water Conservation, 6(1): 28-36, 42. (in Chinese)

Wang X X, Liu T X, Li F L, et al. 2014. Simulated soil erosion from a semiarid typical steppe watershed using an integrated aeolian and fluvial prediction model. Hydrological Processes, 28(2): 325-340.

Xie Y, Lin X J, Liu Y N, et al. 2008. Calibration of simulated rainfall intensity and its spatial distribution for trough rainfall simulator. Bulletin of Soil and Water Conservation, 28(4): 1-6. (in Chinese)

Xu J X. 2005. Hyperconcentrated flows as influenced by coupled wind-water processes. Science in China Series D: Earth Sciences, 48(11): 1990-2000.

Zhang G H, Liu B Y, Li P K. 2007. Principles and properties of artificial through rainfall simulator. Bulletin of Soil and Water Conservation, 27(6): 56-60. (in Chinese)

Zhang G H, Liu G B, Wang G L, et al. 2011. Effects of vegetation cover and rainfall intensity on sediment-bound nutrient loss, size composition and volume fractal dimension of sediment particles. Pedosphere, 21(5): 676-684.

Zhang Q Y, Fan J, Zhang X P. 2016. Effects of simulated wind followed by rain on runoff and sediment yield from a sandy loessial soil with rills. Journal of Soils and Sediments, 16(9): 2306-2315.

Zhao H L, Yi X Y, Zhou R L, et al. 2006. Wind erosion and sand accumulation effects on soil properties in Horqin sandy farmland, Inner Mongolia. CATENA, 65(1): 71-79.

Zou Y R, Zhang Z X, Wang C Y, et al. 2003. Analysis on the distribution characteristics of the interleaving zones of water/wind erosion in China. Arid Zone Research, 20(1): 67-71. (in Chinese) 